\title{
Penerapan Community Based Tourism Di Kampung Lakkang Sebagai Daya Tarik Wisata
}

Hasrullah a, 1, Ida Bagus Suryawan a, 2

${ }^{1}$ hasrullah.halik@gmail.com, ${ }^{2}$ idabagussuryawan@unud.ac.id

a Program Studi S1 Destinasi Pariwisata, Fakultas Pariwisata,Universitas Udayana, Jl. Dr. R. Goris, Denpasar, Bali 80232 Indonesia

\section{Abstract}

This study aims to identify potential that could be being developed as a tourist attraction in Kampung Lakkang. Know the community perspective about the development of tourism. Know the development of tourism in kampung lakkang as tourist attraction and formulate the direction of the development based on the community based tourism aspects.

Data collection techniques in this research is a technique observation, non-structural interview, and documentary method. Data analysis being used was thematic basis analysis. The results concluded that Kampung lakkang having many of tourism potential which rests in that the atmosphere rural and cultural nature. And the community viewed it is very appropriate to being developed as a tourist attraction thought as the currently of it's development was very minimal. This case as caused with the limitation of the community knowledge of tourism, the lack of the community in exploiting the potential as attraction. Paradigma of the community who want to get the results are instant annd the lack of support and grant from the stakeholders, in this case private sector and government.

A conclusion of the development direction in kampung lakkang based upon the root issues concerning as community based tourism with provide provisions for the local community to develop Kampung lakkang, maximize performance disparekraf of makassar by making policy relates to the development of tourism facilities and infrastructure in Kampung lakkang and in partnership with the private stakeholders to supervising the community to increase creativity by making use of the community in creating business have been potential fields that is.

Keywords: Tourism Potential, Community Perspective, Community Based Tourism

\section{PENDAHULUAN}

Penerapan Community Based Tourism ini dilakukan dengan bentuk memberikan kesempatan dalam manajemen dan pembangunan pariwisata yang berujung pada pemberdayaan politis melalui kehidupan yang lebih demokratis termasuk dalam pembagian keuntungan dari kegiatan pariwisata yang adil bagi masyarkat lokal (Purnamasari, 2011).

Pariwisata merupakan salah satu potensi unggulan dan basis pertumbuhan ekonomi di Kota Makassar, Provinsi Sulawesi Selatan. Sebagaimana yang tertuang pada peraturan daerah Nomor 9 tahun 2009 tentang Rencana Tata Ruang Wilayah Sulawesi Selatan, maka Kota Makassar ditetapkan sebagai kawasan terpadu pusat bisnis, sosial budaya dan pariwisata Center Point Of Indonesia (Pusat Bisnis Terpadu Indonesia) di Mamminasata. Strategisnya posisi dan peran Kota Makassar khususnya dalam sektor pariwisata tersebut juga didukung oleh visi pembangunan kota Makassar 2005-2025 yakni "Makassar sebagai Kota Maritim, Niaga, Pendidikan, Budaya dan Jasa yang berorientasi Global,
Berwawasan Lingkungan dan Paling Bersahabat".

Dalam rangka mewujudkan visi, Pemerintah Kota Makassar melakukan pengembangan pariwisata khususnya pada kawasan yang potensial, salah satunya di kelurahan Lakkang, Kecamatan Tallo. Lakkang, memiliki kekayaaan potensi alam dan budaya yang dapat dikembangkan menjadi daya tarik wisata. Tahun 2013, kampung Lakkang telah digodok untuk pengembangannya sebagai kawasan pariwisata melalui program nasional pemberdayaan (PNPM) mandiri pariwisata oleh kementrian kebudayaan dan pariwisata dalam bentuk kelompok pemberdayaan masyarakat berupa BKM (Badan Keswadayaan Masyarakat) yang merupakan program ataupun kebijakan Kota Makassar. Namun saat ini, usaha-usaha pengembangan pariwisata yang berorientasi pada masyarakat lokal masih sangat minim, hal ini terlihat dari beberapa potensi yang terdapat di Kampung Lakkang masih belum mendapat perhatian serius dalam pengembangan serta pengelolaan dengan baik seperti pemanfaatann Potensi Hutan Bambu untuk di olah menjadi souvenir, keberadaan cagar 
budaya bunker di Kampung Lakkang yang masih terbengkalai. Hal lainnya, prasarana wisata yang belum memadai seperti dermaga yang butuh perbaikan karena kondisinya yang sudah tidak layak, dan pemilik transportasi bersifat perseorangan yang belum terorganisir dengan baik. Selain itu, sarana atau fasilitas penunjang kegiatan wisata seperti penginapan bagi wisatawan, rumah makan, pusat informasi dan sarana lainnya hingga saat ini.

Dari permasalahan tersebut masyrakat setempat memandang bahwa kurangnya dukungan dari pihak stakeholder pemerintah setempat dalam melakukan pengembangan adalah salah satu penyebab utama dalam hal ini, serta kurangnya latar belakang pengalaman masyarakat lokal dalam bidang pariwisata dan pola pikir yang ingin mendapatkan hasil instan akibatnya kepedulian masyarakat setempat untuk dapat berpartisipasi dalam memanfaatkan dan mengembangkan potensi wisata di Kampung Lakkang.

Keberadaan potensi wisata di Kampung Lakkang, diperlukannya langkah konkrit dalam pemanfaatan sumberdaya yang bersifat konservatif dengan perumusan suatu konsep pengembangan pariwisata yang memihak pada kepentingan dan kesejahteraan masyarkat lokal. Pemberdayaan masyarakat lokal adalah hal yang utama untuk dipenuhi dengan sebagai pelaku usaha pariwisata (pemilik, pengelola dan karyawan) sehingga pariwisata di Kampung Lakkang menjadi bagian dari sumber penghidupan bagi masyarakat lokal ke depannya.

Salah satu bentuk perencanaan yang partisipatif dalam pengembangan pariwisata adalah pengembangan Community Based Tourism sebagai pendekatan pembangunan yang melibatkan masyarakat lokal sebagai bagian dari manajemen yang turut serta dalam mengambil setiap keputusan dan juga sekaligus masyarakat lokal sebagai pihak yang harus menanggung dampak kumulatif dari perkembangan wisata dengan input yang besar. Berdasarkan latar belakang permasalahan tersebut maka dipandang perlu dilakukan penelitian ini untuk mengetahui bagaimana penerapan
Community Based Tourism di Kampung Lakkang Sebagai Daya Tarik Wisata.

\section{KEPUSTAKAAN}

1. Community Based Tourism Community based tourism (CBT) atau disebut pariwisata berbasis masyarakat merupakan kepariwisataan yang umumnya diselenggarakan dalam skala kecil dimana di dalamnya terjadi interaksi antara pengunjung dan masyarakat tuan rumah. Pariwisata berbasis masyrakat biasanya lebih cocok untuk diterpakan di dearah pedesaan, dikelolah dan dimiliki oleh masyarakat lokal dan untuk masyarakat lokal, dengan mengedepankan penyedia pelayanan pariwisata lokal dan berfokus pada budaya dan lingkungan sebagai daya tariknya (Asker dkk, 2010: 1).

\section{METODE PENELITIAN}

Penelitian ini mengambil lokasi di Kampung Lakkang, yang terletak di daerah territorial Kota Makassar - Provinsi Sulawesi Selatan, tepatnya berada di Delta antara Sungai Tallo dan Sungai Pampang, yang terbentuk sebagai akibat sedimentasi sungai selama ratusan tahun.

Ruang Lingkup Penelitian adalah untuk membatasi penelitian dan mempertegas aspek data yang meliputi :

a. Pandangan masyarakat terhadap pengembangan potensi wisata kampung Lakkang sebagai daya tarik wisata dengan mengacu pada aspek: Kelayakan Potensi Wisata, Keterlibatan masyarakat dalam pengembangan, Usaha-usaha dalam pengembangan, Kendala-Kendala dalam Pengembangan, Keterlibatan Stake Holder dalam pengembangan

Adapun jenis data dalam penelitian ini adalah data kualitatif. Sumber data yang digunakan dalam penelitian ini adalah data primer dan data sekunder. Metode pengumpulan data yang dilakukan adalah observasi, wawancara dan studi dokumentasi. Purposive Sampling adalah teknik pengambilan sampel sumber data dengan pertimbangan tertentu. (Sugiyono, 2014). Teknik analisa data yang digunakan dalam laporan penelitian ini adalah analisis tematik (Poerwandari, 2005). 


\section{HASIL DAN PEMBAHASAN}

\subsection{Gambaran Umum Kampung Lakkang}

Profil Kampung Lakkang Tahun 2013, bahwa Secara administratif, Kampung Lakkang terletak di Kecamatan Tallo, Kota Makassar atau lebih tepat terletak di aliran sungai Tallo di tengah Kota Makassar, luas wilayah ini $1,95 \mathrm{~km} 2$ yaitu $500 \mathrm{~m}$ dari permukaan laut.

Lakkang adalah delta atau bisa disebut pulau yang dikelilingi oleh sungai, dengan lebar sungai 10 meter di bagian depan terdpat dermaga. Secara fisik Kampung Lakkang terdiri dari berbagai karakter wilayah. Sebagian memasuki wilayah permukiman, maka akan ditemukan bentangan Sawah, Empang atau Tambak, pohon Bambu, pohon Nipa dan hutan bakau.

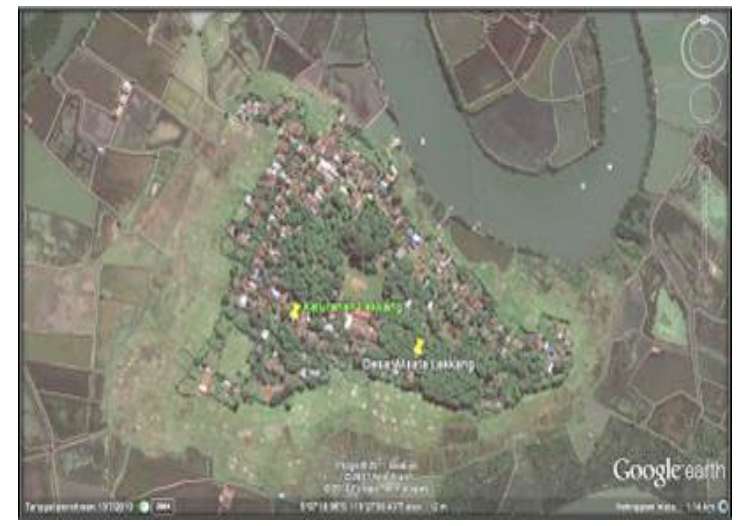

Gambar 4.1 Peta Citra Wilayah Kampung Lakkang.

Sumber : https://www.google.com/maps

\subsection{Pandangan Masyarakat Terhadap Pengembangan Potensi Wisata Kampung Lakkang Sebagai Daya Tarik Wisata.}

\section{Kelayakan Potensi Wisata}

Hasil analisis tematik tentang pandangan masyarakat terhadap kelayakan potensi terdiri dari kebergaman jenis atraksi, pengelolaan DTW yang belum maksimal, aksesibilitas sangat mudah.

Kebergaman jenis atraksi, masyarakat memandang bahwa Kampung lakang memiliki potensi yang sangat baik karena Kampung Lakkang memiliki atraksi yang bukan hanya mengandalkan alam tetapi juga mengandalkan budaya sehingga sangat layak untuk dikembangkan menjadi daya tarik wisata yang unik dan variatif.
Pernyataan yang mewakili komponen ini diberikan oleh R2 dan R4 sebagai berikut:

"Kalau diliat ki potensi na, di kampung lakkang ini banyak sekali bisa dikembangan dan cocok untuk jadi daya tarik wisata. Kaya, potensi alam na sama potensi budaya bermacam-macam ada disini. Seperti, kawasan persawahan, hutan bakau, dan ada juga pohon nipa. Sedangkan untuk potensi budaya na, ada tarian tradisional bugis makassar yang asal usul na memang asli dari Lakkang, ri namai tari pamanca, na punna di kelolai bisa mengundang waisatan berkunjung di Lakkang. (R2-01)

Komponen Pengelolaan DTW yang belum maksimal, masyarakat memandang bahwa pengelolaan DTW di Kampung Lakkang belum dilakukan secara maksimal, hal ini terlihat pada beberapa potensi alam maupun budaya yang terdapat di Lakkang masih terabaikan dan belum mampu memberikan kontribusi kepada masyarakat khususnya pada bidang ekonomi Pernyataan yang mewakili komponen ini diberikan oleh R1 dan R2 sebagai berikut:

"Potensi alam dan budaya na beragam disini, seperti hutan bakau sama kawasan tambak untuk wisata mancing, tarian pamanca dan lainnya, cuman sayang sekali, sampai sekarang belum pi dikelolah dan belum kembangkan dengan baik." (R1-02, R2-02)

Komponen aksesibiltas sangat mudah, masyarakat memandang untuk menuju ke Kampung Lakkang sangat mudah, karena lokasi Kampung Lakkang sangat dekat pusat Kota dan ketersedian beberapa dermaga yang bisa di pilih oleh wisatawan yang ingin berkunjung ke Lakkang. Pernyataan yang mewakili komponen ini diberikan oleh R5 sebagai berikut :

"Akses ke Lakkang, juga masih sangat mudah sekali dan dekat dengan kota, biaya penyebrangan juga cukup masih murah kita kenakan, yaitu sekitar Rp 3000-5000 per orang na." (R5-02)

2. Keterlibatan Masyarakat dalam Pengembangan Potensi Wisata di Kampung Lakkang sebagai Daya Tarik Wisata 
Hasil analisis tematik, pandangan masyarakat terhadap keterlibatan terdiri dari lemahnya keterlibatan masyarakat, pariwisata belum menjadi sektor yang menjanjikan.

Keterlibatan masyarakat pada pengembangan potensi pariwisata di Kampung Lakkang, dipandang masih tergolong rendah, seperti menjadi petugas penyebrangan perahu pincara (dua perahu dirakit menjadi satu) serta pengelolah sampah, dan itupun hanya dilakukan oleh beberapa orang saja. Namun secara umum, masyarakat terlibat dalam menjaga keamanan di Kampung Lakkang. Pernyataan yang mewakili komponen ini diberikan oleh R4 sebagai berikut:

"Secara tidak langsung, sebenarnya sebagian warga disini sudah terlibat ji, kaya' saya kan aktif mengelolah sampah-sampah bekas disini,terus saya dibantu juga beberapa masyarakat". (R4-02)

Komponen pariwisata belum menjadi sektor yang menjanjikan, masyarakat memandang kebaradaan potensi pariwisata di Lakkang belum mampu memberikan kontribusi secara ekonomi khususnya dalam menciptakan lapangan kerja baru, hal ini disebabkan karena keterbatasan pengetahuan masyarakat dalam memanfaatkan dan mengelola potensi yang ada, serta pola pikir masyarakat yang ingin mendapatkan hasil yang bersifat instan. Pernyataan yang mewakili komponen ini diberikan oleh R1 sebagai berikut :

"Masyarakat rinne lebih na pilih pergi cari kerja di kota dari pada mengelolah potensi di Lakkang." (R1-04)

3. Usaha-Usaha dalam Pengembangan Potensi Wisata di Kampung Lakkang sebagai Daya Tarik Wisata

Hasil analisis tematik, pandangan masyarakat terhadap usaha-usaha pengembangan terdiri dari perbaikan sarana dan prasarana yang masih sangat minm dan pengembangan SDM.

Perbaikan saran dan prasarana, masyarakat memandang bahwa sarana dan prasarana pariwisata di Kampung Lakkang saat ini masih sangat minim serta beberapa dari sarana prasarana yang terdapat di Kampung Lakkang sudah banyak yang tidak terawat atau kondisi rusak dan hingga saat ini belum mendapat perhatian secara serius dari pemerintah setempat dalam hal perbaikan atau pemberian bantuan sejak tahun 2013 seperti perbaikan dermaga, pengadaan toilet umum bagi wisatawan yang berkunjung, rumah makan dan lainnya.

Komponen pengembangan SDM, masyarakat memandang bahwa usaha-usaha dalam pengembangan sudah dilakukakan dalam mendukung pengembangan pariwisata di Kampung Lakkang adalah pelatihanpelatihan SDM yakni meliputi pelatihan membuat kerajinan dengan memanfaatkan potensi-potensi yang dimiliki Kampung Lakkang, seperti membuat souvenir dari pohon Bambu serta pelatihan kuliner-kuliner traditional khas Bugis Makassar, namun pelatihan-pelatihan pengembangan SDM tersebut hingga ssat ini sudah jarang dilaksanakan. Pernyataan yang mewakili komponen ini diberikan oleh R2 sebagai berikut.

"Pengembangan SDM, kaya' pelatihanpelatihan buat kearajinan. Disini kan banyak hutan bambu, nah kita pernah mi kita garap dan lakukan pelatihan sama warga untuk bisa memanfaatkan potensi bambu menjadi sesuatu yang bermanfaat buat masyarkat". (R2-05).

\section{Kendala-Kendala dalam Pengembangan Potensi Wisata di Kampung Lakkang sebagai Daya Tarik Wisata}

Keterbatasan anggaran dipandang oleh masyarakat sebagai kendala yang cukup dirasakan oleh pihak pengelolah dan masyarakat dalam pengembangan pariwisata di Kampung Lakkang. Dari berbagai usahausaha yang telah dilakukan sebelumnya seperti pelatihan-peatihan SDM, hingga saat ini sudah tidak pernah lagi dilaksanakan. Hal lainnya, usaha-usaha kecil masyarakat setempat, seperti usaha warung makan serta usaha kerajinan, saat ini sudah terhenti. Dukungan pemerintah dalam bantuan anggaran, dukungan dalam mempromosikan usaha masyarakat diyakini masih sangat kurang dan belum ada keseriusan dalam mendukung pengembangan pariwisata di Kampung Lakkang. Juga, masyarakat memandang bahwa pariwisata di Kampung Lakkang, belum mampu memberikan kontribusi dalam bidang ekonomi seperti tersedia lapangan kerja baru. Hal ini memicu 
masyarakat untuk memilih mencari pekerjaan di Kota. Pernyataan yang mewakili komponen ini diberikan oleh R2 dan R5 sebagai berikut:

"Dukungan dari pemerintah, masih sangat kurang sekali. Seperti tadi saya bilang, kalau perahu pincara cuman sekali ji kita dapat bantuan dari pihak pemerintah, nah kalau memang serius harus na kita dapat perhatian. Terus faktor masyarakat juga disini, masih kurang berminat untuk ikut mengembangkan potensi di Lakkang, seperti lahan empang warga disini, dibiarkan begitu, tidak diurusi bahakan lebih banyak menyebrang ke Kota untuk bekerja" (R5-06 dan R5-07).

\section{Keterlibatan Stakeholder dalam Pengembangan Potensi Wisata di Kampung Lakkang sebagai Daya Tarik Wisata}

Keterlibatan pihak swasta dalam mendukung pengembangan pariwisata di Kampung Lakkang, masyarakat setempat memandang bahwa beberapa pihak stakeholder swasta sudah memberikan partisipasinya khsusus dalam bantuan pengembangan sarana dan prasarana, seperti pengadaan tempat sampah di beberapa titik tertentu serta perbaikan dermaga penyebrangan yang tentunya dapat memberikan kasadaran serta edukasi bagi masyarakat maupun wisatawan untuk tidak membuang sampah sembarangan. Juga mempermudah akesibilitas, memberikan kenyamanan masyarakat dan wisatawan yang ingin berkunjung ke Kampung Lakkang. Hal lainnya, pihak stake holder telah terlibat dalam pemberian informasi di beberapa obyek wisata berupa papan informasi atau petunjuk yang dapat membantu wisatawan untuk lebih mudah mengakases obyek wisata yang ada di Kampung Lakkang. Sedangan pada pihak pemerintah, masyarakat memandang keterlibatan pemerintah dalam pengembangan pariwisata di Kampung Lakkang yakni berupa bantuan anggaran PNPM Mandiri pada tahun 2013, namun bantuan anggaran tersebut belum dirasakan secara merata oleh masarakat lokal kampung Lakkang, seperti bantu perbaikan sarana transporatsi sungai serta prasarana dermaga yang hingga saat ini belum pernah tersentuh. Pernyataan yang mewakili komponen ini diberikan oleh R2 dan R5 sebagai berikut:
"Dari stake holder swasta, itu ada yayasan kalla dan Bank Mandiri. Kita pernah dapat bantuan berupa perbaikan dan sarana dan prasarana, seperti perbaikan dermaga penyebrangan dan pengadaan tempat-tempat sampah. Terus dari pihak pemerintah sendiri, berupa anggaran dana PNPM pada tahun 2013" (R4-07 dan R4-08).

\section{PENUTUP}

A. Simpulan

Berdasarkan hasil pembahasan maka dapat ditarik kesimpulan sebagai berikut;

Pengembangan potensi wisata di Kampung Lakkang sebagai daya tarik wisata dipandang oleh masyarakat sangat layak karena memiliki keberagaman jenis atraksi. Potensi wisata yang dapat dikembangkan terdiri dari dari wisata alam, budaya dan sejarah. Untuk mengembangkaan potensipotensi wisata yang ada, maka diperlukan arahan pengembangan berdasarkan konsep community based tourism yakni meningkatkan kesadaran, wawasan, pola pikir, dan motivasi masyarakat terkait pemanfaatan potensi pariwisata di Kampung Lakkang melalui tokoh masyarakat dalam setiap aktivitas sosial yang rutin terjadi seperti PKK, pertemuan warga rutin, dan pertemuan keagamaan. Memaksimalkan kinerja disparekraf Kota Makassar dengan membuat kebijakan terkait pengembangan sarana dan prasarana pariwisata di Kampung Lakkang serta menggandeng pihak-pihak stakeholder swasta dalam melakukan pembinaan terhadap masyarakat untuk meningkatkan kreatifitas masyarakat dalam menciptakan usaha dengan memanfaatkan potensi-potensi yang ada. Kerjasama antara Dinas Pariwisata Kota Makassar dengan masyarakat pemilik bangunan di Kampung Lakkang dalam mengintegrasikan bangunan milik pribadi sebagai penunjang kegiatan wisata di Kampung Lakkang dengan tujuan meningkatkan peran masyarakat, yaitu: pemberian hak dan kewajiban mengelola kepada pemilik bangunan di Kampung Lakkang, pemberian hak ini dapat berupa insentif seperti pembebasan PBB atau biayabiaya lainnya sedangkan pemilik bangunan wajib bertanggung jawab dalam mengelola bangunannya.

B. Saran 
Pengembangan potensi wisata di Kampung Lakkang sebagai daya tarik wisata, sekiranya dilakukan pendampingan bagi masyarakat sebagai bagian integral dari pengembangan aspek-aspek kepariwisataan. Kerjasama yang baik antara masyarakat

\section{DAFTAR PUSTAKA :}

Anonim. 2015. Peraturan Daerah No.9 Tahun 2009 Tentang Rencana Tata Ruang Wilayah Sulawesi Selatan.

Asker, S., Boronyak, L., Carrard N., and Paddon, M., 2010. Effective Community Based Tourism, A best Practical Manua. Singapore : Suistanable Tourism Cooperative Research.

Dina, Yuniati. 2010. Pemetaan Dampak Ekonomi Pariwisata Dalam Penerapan Konsep Community-Based Tourism. UNS

Purnamasari, Andi Maya. (2011), Pengembangan Masyarakat Untuk Pariwisata Di Kampung Wisata Toddabojo Provinsi Sulawisi Selatan, Jurnal Perencanaan Wilayah Dan Kota, Vol 22, 49-64

Paturusi, Syamsul Alam. 2001. Perencanaan Kawasan Pariwisata. Universitas Udayana. Denpasar.

Poerwardarminta, W.J.S. 2002. Kamus umum Bahasa Indonesia. Balai Pustaka. Jakarta

Sugiyono. 2014. Metode Penelitian Kuantitatif, Kualitatif, dan $R \& D$. Bandung: Alfabeta.

Yaman Amat Ramsa dan mohd Abdullah. 2004. Community based Ecotourism: A New Proposition for Sustainable Development and Environmental Conservation in Malaysia. Journal of applied sciences

Yoeti, Oka. A. 2001. "Manajemen Pariwisata", Jakarta: Pradnya Paramita

Wisantisari, Purwani, 2005, Penyajian Informasi Pariwisata Di Kabupaten Tegal Berbasis Sistem Informasi (Sig), Semarang : Uneversitas Negeri Semarang.

Sumber Lain

Profil Kampung Lakkang tahun 2013 setempat sebagai pelaku utama pengembangan wisata dan peran pemerintah dan swasta sebagai fasilitator. 